\title{
Founder effects and geographical variation in the invading cladoceran Bosmina (Eubosmina) coregoni Baird 1857 in North America
}

\author{
RITA DEMELO AND PAUL D. N. HEBERT* \\ Department of Zoology, University of Guelph, Guelph, Ontario, Canada N1G 2W1
}

\begin{abstract}
Invasions and subsequent range expansions by exotic species provide an excellent opportunity for the study of founder effects on the genetic structure of colonizing populations. Although the Great Lakes have served as the initial point of colonization for more than 100 species, few studies have examined the genetic structure of these invaders. This study shows that levels of genetic variability in North American populations of the cladoceran invader Bosmina coregoni are at least as high as those in European populations, suggesting that founding populations were large. As allelic diversity in North America is higher than in any single European population, the Great Lakes have probably been colonized repeatedly. In the past 30 years, B. coregoni has expanded its range into inland lakes within $100 \mathrm{~km}$ of the Great Lakes, through both long-distance dispersal and migration among neighbouring lakes. Although these secondary invasions have produced little reduction in genetic diversity, they have led to pronounced gene frequency divergence among populations from inland North American lakes.
\end{abstract}

Keywords: allozymes, Bosminia coregoni, genetic variation, species invasions.

\section{Introduction}

The potential importance of founder events in reducing heterozygosity and creating genetic divergence among populations has often been emphasized as a primary factor in evolutionary divergence and speciation (Mayr, 1963; Carson, 1967; Templeton, 1980). In practice, however, founder effects cannot be easily distinguished from the effects of selection (Coyne \& Barton, 1988). Moreover, the impact of founder events need not be substantial. A loss of heterozygosity will not occur if population increase is rapid following colonization (Nei et al., 1975). In addition, unless the number of founders is very small, only rare alleles, which contribute little to overall genetic variability, are lost (Lewontin, 1965). The invasion of exotic species into new habitats and their subsequent range expansion provides an excellent opportunity for the study of founder effects on the genetic structure of populations. Although several studies have examined founder effects in such settings, few have provided evidence of its importance (Parkin \& Cole, 1985; Baker \& Mooed, 1987).

${ }^{*}$ Correspondence.
Since the 1880 s the Great Lakes have served as the initial point of colonization for at least 136 exotic species (Mills et al., 1991). Most of these invaders have arrived within the last 30 years, associated with the opening of the Great Lakes to transoceanic freighters. In many cases, these invaders have subsequently extended their ranges into neighbouring lakes via secondary founder events. Few studies have so far examined the genetic structure of these invaders. Boileau \& Hebert (1992) found no loss of genetic variation in Great Lakes populations of the zebra mussel Dreissena polymorpha compared with European populations and observed alleles in North America which were absent from reference populations in Europe. An examination of another invader in the Great Lakes, the cladoceran Bythotrephes cederstroemi, found low levels of polymorphism, but no European populations were analysed (Weider, 1991).

This study examines patterns of genetic diversity in the cladoceran Bosmina (Eubosmina) coregoni (Baird, 1857), a species endemic to Eurasia (Lieder, 1991), which apparently first invaded the Great Lakes in the mid-1960s via ship ballast water (Lieder, 1991; Mills et al., 1991). It was initially detected in Lake Michigan in 1966 (Wells, 1970) and by 1971 had become one of 
the dominant cladocerans in the Great Lakes (Balcer $e t$ al., 1984). By 1968 it dispersed to inland lakes (Deevey \& Deevey, 1971), and by 1980 the species was known from lakes in both southern Ontario and northern New York State (Carter et al., 1980).

There is no direct information on either the source(s) or the number of colonists responsible for the establishment of $B$. coregoni in North America. However, it is apparent that the invasion of this species into the Great Lakes corresponds to a primary founder event whereas its subsequent expansion into inland lakes represents secondary events. This study aimed particularly to compare the extent of genetic divergence and levels of genetic variability between European populations of $B$. coregoni and those from both the Great Lakes and the inland lakes. The study also aimed to ascertain if genetic differences between inland lake populations and those in the Great Lakes were related simply to distance or whether subsidiary factors such as interconnection were important.

\section{Materials and methods}

\section{Collections}

North American samples of $B$. coregoni were collected between May 1990 and August 1992 from 22 inland lakes in Ontario, New York State, Michigan, Wisconsin and Indiana, as well as from three sites in Lake Ontario and one site in Lake Erie (Table 1). The European samples were collected in November 1991 and July-September 1993 from 12 lakes in Germany, the Czech Republic and the Netherlands (Table 1). Individuals were either flash-frozen in liquid nitrogen or returned alive for electrophoretic analysis.

\section{Electrophoresis}

Individual allozyme phenotypes were assayed on cellulose acetate gels according to the methods of Hebert \& Beaton (1989) but with modifications (DeMelo, 1993). Eight enzymes representing nine loci were screened for all populations. These loci were aspartate aminotransferase $(A a t)$, arginine phosphokinase $(A p k)$, fumarase $($ Fum $)$, glucose phosphate isomerase $(G p i)$, lactate dehydrogenase $(L d h)$, malate dehydrogenase $(M d h)$, phenylalanylproline peptidase $(P e p D)$ - two loci- and phosphoglucomutase $(P g m)$. Bands were assumed to represent the products of alleles at a single locus, as heterozygous phenotypes conformed to those expected from the quaternary structure of the enzyme (Ward, 1977). Alleles were numbered according to increasing anodal mobility of their allozyme products (i.e. the allozyme corresponding to allele 1 exhibited the slowest mobility). A $\chi^{2}$ heterogeneity test (Workman \& Niswander, 1970) was used to examine the significance of variation in genotypic frequencies among sites in Lake Ontario; homogeneous samples were pooled $(P<0.05)$.

Table 1 Sample sites in North America and Europe. ABR, sample abbreviation; IND, Indiana; $\mathrm{MICH}$, Michigan; WIS, Wisconsin; NY, New York State; ONT, Ontario; GL, Great Lakes; GER, Germany; CZECH, Czech Republic; NETH, the Netherlands

\begin{tabular}{ll}
\hline Lake/reservoir & ABR \\
\hline North America & \\
Waldron & IND-1 \\
Wabee & IND-2 \\
Tippecanoe & IND-3 \\
James & IND-4 \\
Webster & IND-5 \\
Kuhn & IND-6 \\
Winona & IND-7 \\
Eagle & MICH-1 \\
Wingra & WIS-1 \\
Salmon River & NY-1 \\
Oneida & NY-2 \\
Gordon Pittock & ONT-1 \\
Wildwood & ONT-2 \\
Conestogo & ONT-3 \\
Bellwood & ONT-4 \\
Guelph & ONT-5 \\
Eugenie & ONT-6 \\
Simcoe & ONT-7 \\
Sturgeon & ONT-8 \\
Scugog & ONT-9 \\
Stony & ONT-10 \\
Rice & ONT-11 \\
L.Erie - Rondeau & GL-1 \\
L. Ontario - Hamilton Harbour & GL-2 \\
L.Ontario Midlake & GL-3 \\
L.Ontario - Bay of Quinte & GL-4 \\
Europe & \\
Slapy & CZECH-1 \\
Zevlika & CZECH-2 \\
Diek See & GER-1 \\
Garren See & GER-2 \\
Kleiner Plöner See & GER-3 \\
Pluß See & GER-4 \\
Schaal See & GER-5 \\
Schieren See & GER-6 \\
Schöh See & GER-7 \\
Stechline See & GER-8 \\
Stock See & GER-9 \\
Nieuwe Polderplas & NETH-1 \\
\hline & \\
\hline & \\
\hline
\end{tabular}




\section{Analyses}

All analyses of the allozyme data were performed with BIosys-1 (Swofford \& Selander, 1981). Allele frequencies at the nine presumptive loci were determined by direct count, genetic similarities between all 38 populations were estimated using Rogers' (1972) method and the data were used to construct an Unweighted-PairGroup-Matrix Analysis (UPGMA) dendrogram.

The extent of genetic variation within populations was estimated using three variables: the percentage of polymorphic loci, the mean number of alleles per locus and observed heterozygosity. The extent to which founder events and genetic drift have altered levels of genetic variation in North American versus European populations was analysed by a two-sample $t$-test (Zar, 1984) on the means of the numbers of alleles per locus and the arcsine transformed means for the percentages of polymorphic loci. Observed heterozygosities across all polymorphic loci were compared using the arcsine transformed values with a pairwise $t$-test (Archie, 1985).

The extents of genetic differentiation and population structuring in Europe and North America were quantified using a modified formula for $F_{\mathrm{ST}}\left\langle\Theta=F_{\mathrm{ST}}\right.$, Weir \& Cockerham, 1984). A weighted average of $F_{\mathrm{ST}}$ values across alleles was calculated for each polymorphic locus and a mean value ( \pm standard error) was then calculated across all polymorphic loci. A $\chi^{2}$ heterogeneity test (Workman \& Niswander, 1970) was used to determine if $F_{\mathrm{ST}}$ values deviated significantly from zero.

Geographical patterns of genetic variation in North American populations were examined using the general regression method developed by Mantel (in Sokal, 1979) and by multidimensional scaling (Lessa, 1990). Three models of population structure were examined.

1 An isolation-by-distance model, in which migration to new habitats occurred as an inverse function of distance.

2 A stepping-stone model, in which migrants were exchanged only between adjacent populations.

3 An island model, in which migration occurred at random among all populations.

The genetic consequences of each of these models are predictable. Model 1 results in an increase in genetic distance between populations as the distance between them increases whereas in model 2 adjacent populations are more genetically similar than nonadjacent populations. By contrast, in model 3, geographical distances among populations are not linked to geographic proximity or physical interconnectedness.

The genetic distance matrix (Rogers, 1972) was correlated to various matrices of physical proximity using the Mantel method (in Sokal, 1979). A geographical distance matrix (GEO) was employed to test an isolation-by-distance model, in which populations in close proximity to each other would be more genetically similar than populations distant from each other. A second matrix (LAK) assumed that migration occurred among interconnected water bodies irrespective of their physical immediacy (DeMelo, 1993). A value of one was assigned to all populations within a lake system and a value of zero to populations from different systems. A third matrix (ADJ) was more restrictive, presuming that migration was restricted to adjacent lakes (DeMelo, 1993), as in a stepping-stone model. Only pairs of lakes that were physically connected were considered as adjacent, with a value of one assigned to such pairs of lakes, and a zero to other lakes. Multidimensional scaling (MDS) was used to test for the presence of nonhierarchical patterns of variation, such as reticulate or clinal patterns among the populations (Lessa, 1990).

\section{Results}

The electrophoretic analysis of 26 North American and 12 European populations of $B$. coregoni led to the detection of 19 alleles at the nine enzyme loci (Tables 2 and 3). Five of these nine loci (Aat, Gpi, PepD-1, $P e p D-2$, and $P g m$ ) were commonly polymorphic. The $A p k$ locus varied in only one European and two North American populations whereas the $L d h$ locus was only variable in two European populations. The remaining two loci (Fum and $M d h$ ) were identically monomorphic in all 38 populations. No fixed differences were observed between populations of $B$. coregoni from North America and those from Europe (Table 3) and the minimum genetic similarity between these populations was 0.81. A UPGMA of the genetic relatedness among the populations (Fig. 1) showed that European populations were scattered throughout the dendrogram.

Although two alleles $\left(L d h^{2}\right.$ and $\left.P g m^{2}\right)$ were unique to European populations (Table 3), five alleles were unique to North America. Surprisingly, two of these five North American alleles were not found in the Great Lakes but were unique to inland lakes. There was, however, no significant difference in the mean number of alleles per locus, the percentage of polymorphic loci or individual heterozygosity between European populations and either the Great Lakes or North American inland lakes (Table 4). Also, there was no significant difference between levels of genetic variability in the Great Lakes and inland lake populations (Table 4).

Significant differentiation of allele frequencies was detected for all loci among both the North American 


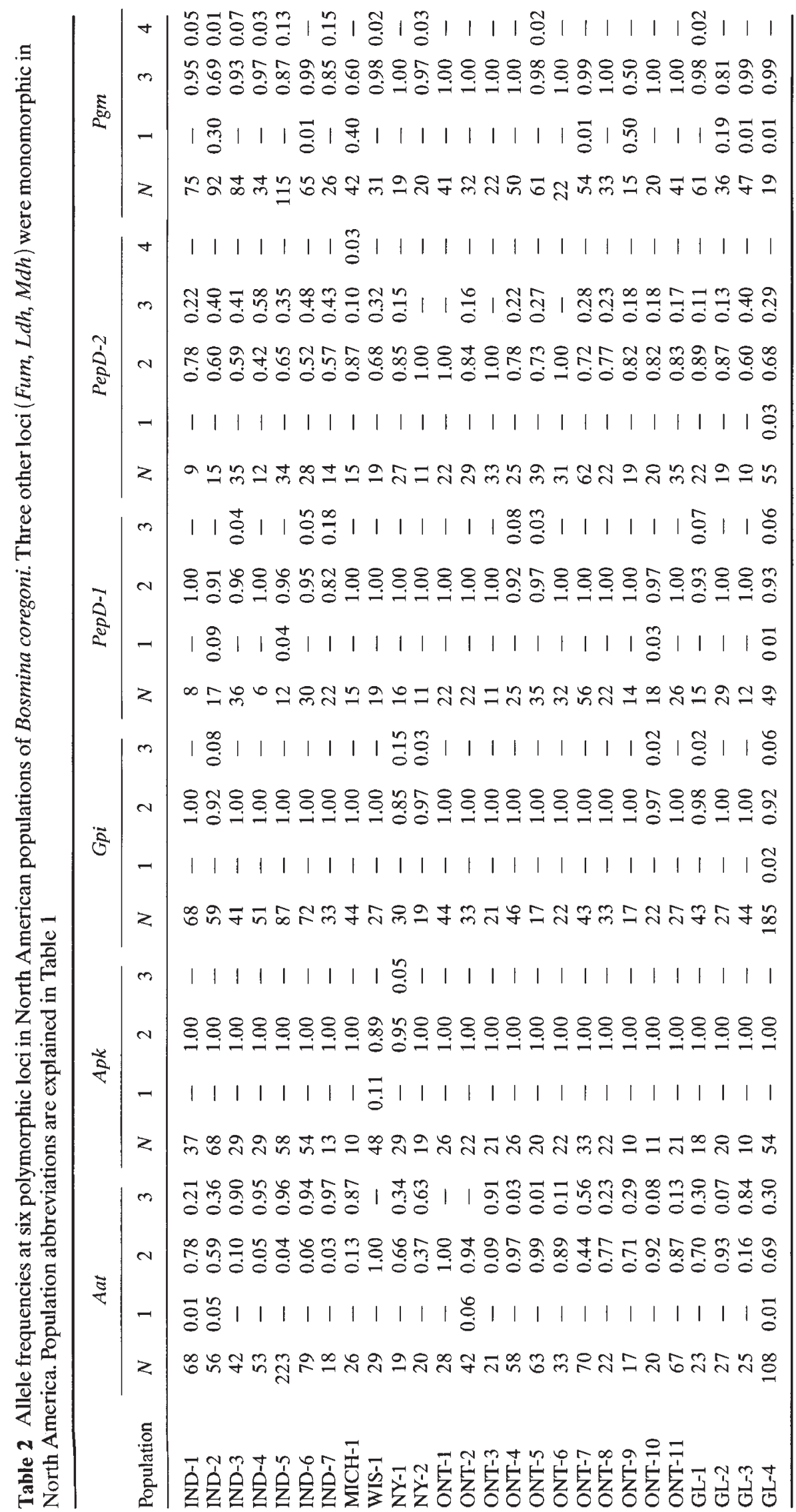




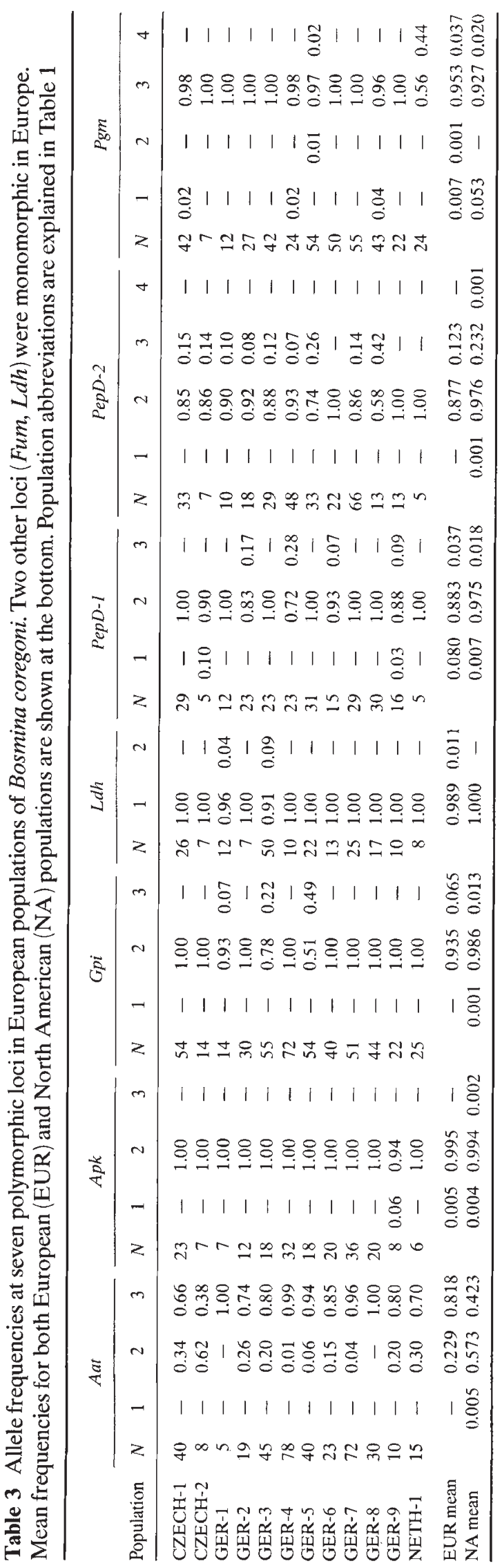

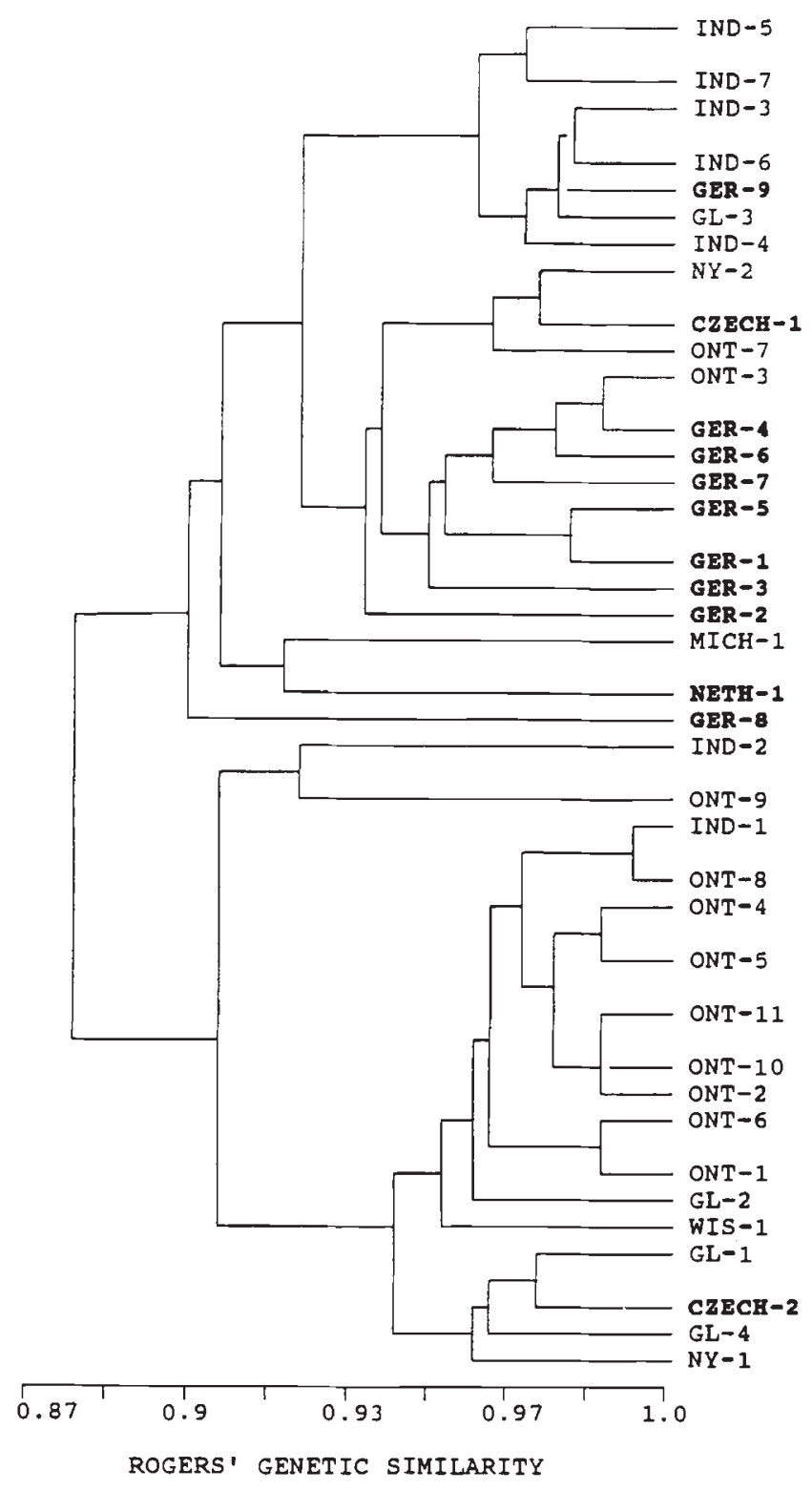

Fig. 1 UPGMA dendrogram of genetic distances among 38 populations of Bosmina coregoni from Europe and North America. Cophenetic correlation $=0.81$. Sample abbreviations are given in Table 1.

and the European populations, except for PepD-1 in the Great Lakes (Table 5). On average, approximately one-fifth of the total variance of allele frequencies in both the Great Lakes and Europe was due to genetic differences between populations (mean $F_{\mathrm{ST}}=0.16 \pm 0.04$ and $0.18 \pm 0.02$ for Great Lakes and Europe, respectively). More pronounced gene frequency divergence was observed for the inland lakes, where the average $F_{\text {ST }}$ was $0.36 \pm 0.09$. Gene frequency divergence was most pronounced at the Aat locus in North American inland lake populations. While two of the three Aat alleles were common in the 
Table 4 Sample size and genetic characters in North American and European populations. $N$, mean sample size per locus; $n_{\mathrm{a}}$, mean number of alleles per locus; $p$, mean percentage of polymorphic loci $\left(0.95\right.$ criterion); $H_{\mathrm{o}}$, mean observed heterozygosity. No significant difference was noted for any of the $t$-tests at the 0.05 significance level

\begin{tabular}{lrrrrrrrrrr}
\hline & Europe vs. & $\begin{array}{l}\text { Great } \\
\text { Lakes }\end{array}$ & $t$ & Europe vs. $\begin{array}{c}\text { Inland } \\
\text { lakes }\end{array}$ & $t$ & $\begin{array}{r}\text { Great } \\
\text { Lakes }\end{array}$ & $\begin{array}{l}\text { Inland } \\
\text { lakes }\end{array}$ & $t$ \\
\hline$N$ & 24.10 & 38.10 & & 19.40 & 31.30 & & 38.10 & 31.30 & \\
$n_{\mathrm{a}}$ & 1.31 & 1.55 & 1.43 & 1.31 & 1.31 & 0.13 & 1.55 & 1.31 & 1.35 \\
$p$ & 25.90 & 33.30 & $1.52^{*}$ & 25.90 & 23.70 & $0.77^{*}$ & 24.40 & 23.70 & $2.13^{*}$ \\
$H_{\mathrm{o}}$ & 0.09 & 0.08 & $1.31 \dagger$ & 0.09 & 0.08 & $2.25 \dagger$ & 0.08 & 0.08 & $0.84 \dagger$ \\
\hline
\end{tabular}

*Means of the arcsine transformed values of $(p \times 100)$ used to obtain the $t$ values.

$\dagger t$ values obtained from pairwise $t$-tests using mean heterozygosity across all polymorphic loci.

Table $5 F_{\text {ST }}$ values at allozyme loci polymorphic in North American and European populations of Bosmina coregoni. Mean $F_{\mathrm{ST}}$ values $( \pm \mathrm{SE}$ ) were calculated across all polymorphic loci using weighted values. All values except those designated by an * were significantly different from 0.0 $(P<0.05)$

\begin{tabular}{lccc}
\hline Locus & Europe & Great Lakes & Inland lakes \\
\hline Apk & $0.04^{*}$ & - & 0.08 \\
Aat & 0.17 & 0.29 & 0.63 \\
Gpi & 0.36 & 0.03 & 0.09 \\
Ldh & $0.04^{*}$ & - & - \\
PepD-1 & 0.15 & $0.01^{*}$ & 0.06 \\
PepD-2 & 0.07 & 0.06 & 0.11 \\
Pgm & 0.31 & 0.16 & 0.21 \\
Mean & & & \\
$F_{\text {ST }}$ & 0.18 & 0.16 & 0.36 \\
& $( \pm 0.02)$ & $( \pm 0.04)$ & $( \pm 0.09)$ \\
\hline
\end{tabular}

Great Lakes, seven inland lake populations were fixed for $A a t^{2}$ and the $A a t^{3}$ allele was dominant in most Indiana lakes (Fig. 2). Variance in Gpi frequencies was apparently more pronounced in the European populations than in the North American but this was largely because of a major gene frequency shift in one German population. Within North America, inland lake populations showed consistently more gene frequency variation than was detected for populations in the Great Lakes.

The results of the Mantel tests (Table 6) showed no significant correlation between geographical and genetic distances (GEO versus ROG). However, a significant correlation was observed between genetic distances and both matrices linked to lake interconnection (LAK and ADJ). These results were similarly suggested by the UPGMA dendrogram (Fig. 1) in which populations from a common geographical area, such as a lake system, generally occurred within the same subcluster.
The MDS analysis (Fig. 3) was in general agreement with the UPGMA dendrogram, as it identified the same two major clusters and subclusters in the dendrogram. Approximately 95 per cent $\left(R^{2}=0.947\right)$ of the variation was recovered by two dimensions of the MDS analysis. The majority of populations collected from Ontario were clearly segregated from all but two Indiana populations.

\section{Discussion}

In the 30 years since its introduction to North America, B. coregoni has only spread to inland lakes within approximately $100 \mathrm{~km}$ of the Great Lakes whereas other aquatic invaders have shown much more rapid rates of expansion (Woodruff et al., 1985; Havel \& Hebert, 1993). Its slow range expansion resembles that seen in the cladoceran Bythotrephes cederstroemi, which has also colonized only those inland lakes in proximity to the Great Lakes (Yan et al., 1992). Carter et al. (1980) reported that B. coregoni occurs only in hard water lakes, which suggests that its spread may have been slowed by habitat requirements.

This study confirmed the close genetic similarity of European and North American populations of $B$. coregoni with an average genetic similarity of 0.87 , a value typical of geographically separated populations of a species (Avise, 1975). Populations of $B$. coregoni from the Great Lakes were at least as genetically variable as their European counterparts, a result suggesting that large numbers of founders colonized the Great Lakes. This broad array of alleles may result from the continued influx of migrants into the Great Lakes system via ship ballast water (Lieder, 1991; Mills et al., 1991) because a study of the ballast water biota of ships entering the Great Lakes confirmed that Bosmina were the most abundant cladocerans, occuring in densities up to four times that of Lake Ontario maxima (Balcer et al., 1984; EPS, 1981).

The presence of various subsets of North American alleles in different European populations and of unique 


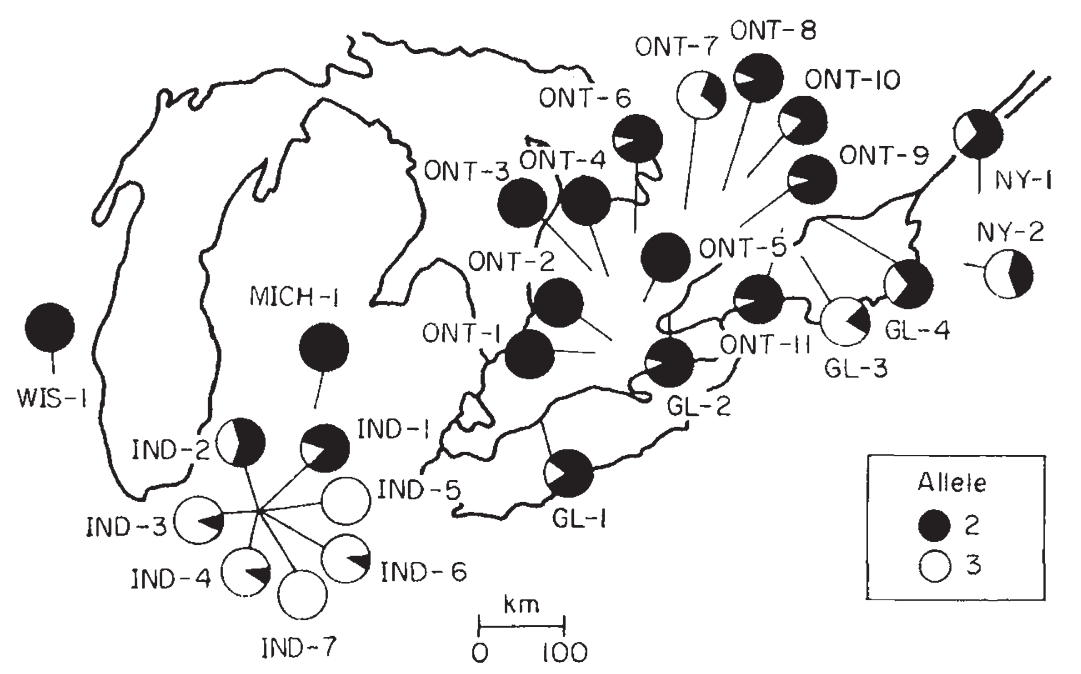

Fig. 2 Variation in allele frequencies of Aat in North American populations of Bosmina coregoni.
Table 6 Summary of the results of the Mantel tests. GEO, matrix of geographical distance; LAK, matrix of interconnecting lakes within a system; ADJ, matrix of interconnecting adjacent lakes; $N$, size of matrix. GEO, LAK and ADJ were tested with a matrix of Roger's genetic distance (ROG); $Z$, calculated Mantel statistic; $Z_{\text {exp }}$, expected values of Mantel statistic; $\sigma^{2}$, variance of $Z ; r$, Pearson product-moment correlation coefficient

\begin{tabular}{rrrrcrr}
\hline & $N$ & $Z$ & $Z_{\exp }$ & $\sigma^{2}$ & $r$ & $\begin{array}{c}P \\
\text { value }\end{array}$ \\
\hline GEO & 26 & 15898.0 & - & - & 0.31 & 0.996 \\
LAK & 16 & 2.8 & 5.1 & 0.3 & -0.45 & $0.004^{*}$ \\
ADJ & 14 & 0.9 & 1.4 & 0.1 & -0.19 & $0.024^{*}$ \\
\hline
\end{tabular}

*Indicates a significant association between the matrices $\langle\alpha=0.05$ ).

alleles in North America strongly suggests the multiple origins of founders. Scattered placement of European populations among North American populations in the UPGMA dendrogram also supports the same conclusion. Although large numbers of individuals probably invaded the Great Lakes, fewer individuals might have invaded inland lakes. However, a decline in allelic diversity in inland lake populations was not observed, which suggests that most inland lake populations have also been established by large transfers of individuals. Surprisingly, five alleles present in North American populations were not detected in European populations. Four of these unique alleles might have been introduced into $B$. coregoni through hybridization and introgression with other North American bosminid taxa (DeMelo \& Hebert, 1994), as has been reported for Daphnia (Taylor \& Hebert, 1993). However, as no evidence of $F_{1}$ hybrids was obtained among bosminid taxa in North America (DeMelo \& Hebert, 1994), it seems probable that the alleles originated in other Eurasian populations of $B$. coregoni.

Founder effects may also be responsible for the pronounced gene frequency divergence observed among populations in North America, in particular, the inland lakes which possessed a mean $F_{\mathrm{ST}}$ twice that found in either the Great Lakes or European inland lakes. The relatively high $F_{\mathrm{ST}}$ values among North American inland populations of $B$. coregoni reflected differentiation among populations separated by only a few kilometers, similar to the results of other studies of freshwater invertebrates (Hebert, 1974; Hebert \& Payne, 1985; Boileau \& Hebert, 1991), which suggests limited dispersal between populations (Hebert, 1987; Weider, 1989). The nature of gene frequency variation among inland populations of $B$. coregoni may suggest a population structure that genetically approximates a stepping-stone model in which migration largely occurs between adjacent habitats. The MDS analysis suggests that migration into these lakes has proceeded from lakes in both the western and eastern regions of the Great Lakes watershed but a more extensive survey is required to decipher further migration paths.

The similarity in levels of genetic variation between European and North American populations of $B$. coregoni is concordant with the results of studies on other introduced species (Table 7). Only two of 12 studies reported a significant loss of genetic variation in introduced populations (Parkin \& Cole, 1985; Baker \& Mooed, 1987), whereas the remaining studies found less drastic alterations in the genetic variability of invaders, usually characterized by a loss of rare alleles (Taylor \& Gorman, 1975; Bryant et al., 1981; Ross, 1983; Janson, 1987; Johnson, 1988; Ross \& Trager, 1990; Baker, 1992). In two cases there was evidence that invading populations were more genetically 
Fig. 3 MDS plot of genetic similarity among populations of Bosmina coregoni in North America. $\mathrm{R}^{2}=0.947$ for two dimensions. Sample abbreviations are given in Table 1. Group I, IND-3 to IND-7; group II, ONT-1, ONT-2, ONT-4 to ONT-6, ONT-8, ONT-10, ONT-11.

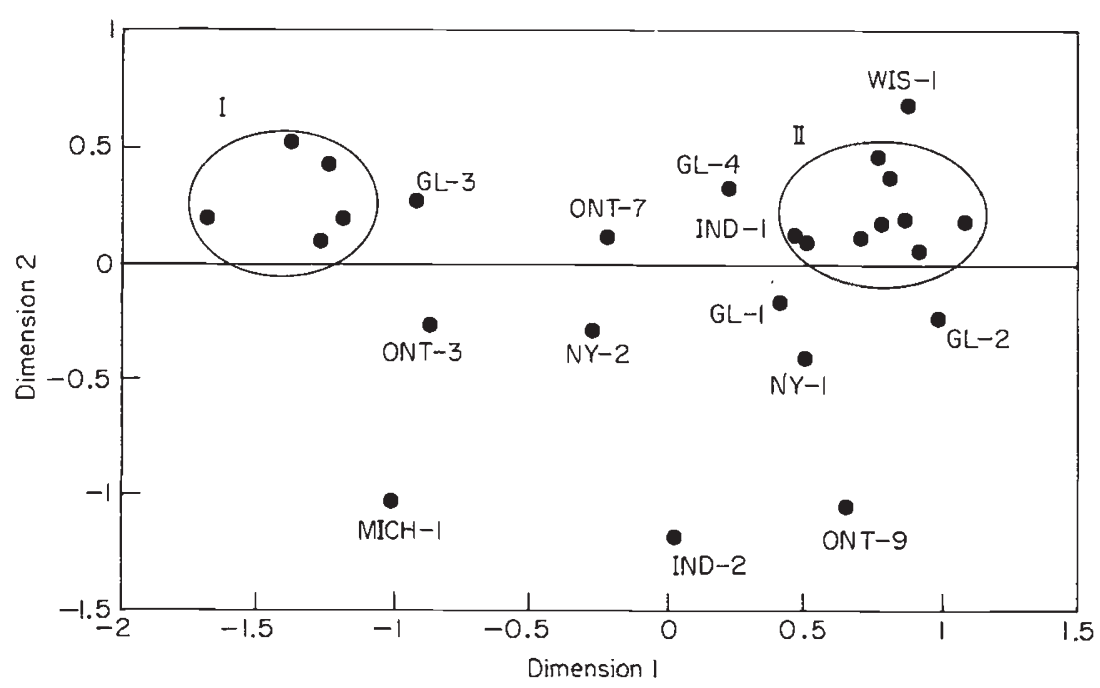

Table 7 Summary of the results of some studies on founder effects in animals. $N$, number of colonists; $\mathrm{T}$, number of years since first colonization event (known or estimated date); Site, location of populations; $H_{\mathrm{e}}$, mean expected heterozygosity; $n_{\mathrm{a}}$, mean number of alleles per locus

\begin{tabular}{|c|c|c|c|c|c|c|c|c|c|}
\hline \multirow[b]{2}{*}{ Species } & \multirow[b]{2}{*}{$N$} & \multirow[b]{2}{*}{$\mathrm{T}$} & \multicolumn{3}{|c|}{ Native } & \multicolumn{3}{|c|}{ Introduced } & \multirow[b]{2}{*}{ Reference } \\
\hline & & & Site & $H_{\mathrm{e}}$ & $n_{\mathrm{a}}$ & Site & $H_{\mathrm{e}}$ & $n_{\mathrm{a}}$ & \\
\hline \multicolumn{10}{|l|}{ Invertebrates } \\
\hline $\begin{array}{l}\text { Theba pisana } \\
\text { (land snail) }\end{array}$ & $?$ & 90 & Various & 0.10 & 1.5 & W. Aus. & 0.05 & 1.2 & Johnson, 1988 \\
\hline \multirow{2}{*}{$\begin{array}{l}\text { Dreissena polymorpha } \\
\quad \text { (zebra mussel) }\end{array}$} & \multirow[t]{2}{*}{$?$} & \multirow[t]{2}{*}{$<10$} & Europe & 0.46 & 2.6 & Great Lakes & 0.50 & 2.8 & \multirow[t]{2}{*}{ Boileau \& Hebert, 1992} \\
\hline & & & Great Lakes & 0.50 & 2.8 & L. Oneida & 0.36 & 2.7 & \\
\hline $\begin{array}{l}\text { Musca autumnalis } \\
\quad \text { (face fly) }\end{array}$ & $?$ & 30 & Europe & 0.05 & 1.6 & USA & 0.04 & 1.5 & Bryant et al., 1981 \\
\hline $\begin{array}{l}\text { Solenopsis richteri } \\
\quad \text { (fire ant) }\end{array}$ & $?$ & $<100$ & Argentina & 0.03 & 1.6 & USA & 0.02 & 1.2 & Ross \& Trager, 1990 \\
\hline (cladoceran) & $?$ & $<30$ & Great Lakes & 0.10 & 1.6 & Inland & 0.08 & 1.3 & This study \\
\hline \multicolumn{10}{|l|}{ Vertebrates } \\
\hline $\begin{array}{l}\text { Anolis grahami } \\
\quad \text { (lizard) }\end{array}$ & 71 & 72 & Jamaica & 0.08 & 1.8 & Bermuda & 0.06 & 1.5 & Taylor \& Gorman, 1975 \\
\hline $\begin{array}{l}\text { Passer domesticus } \\
\quad \text { (house sparrow) }\end{array}$ & $40-400$ & $?$ & Europe & 0.10 & 3.0 & Aus./NZ & 0.09 & 2.5 & Parkin \& Cole, 1985 \\
\hline $\begin{array}{l}\text { Acridotheres tristis } \\
\text { (common myna) }\end{array}$ & $6->100$ & $27-120$ & India & 0.06 & 1.6 & Various & 0.05 & 1.2 & Baker \& Mooed, 1987 \\
\hline $\begin{array}{l}\text { Fringilla coelebs } \\
\text { (chaffinch) }\end{array}$ & $100-400$ & 120 & Europe & 0.05 & 1.3 & $\mathrm{NZ}$ & 0.07 & 1.4 & Baker, 1992 \\
\hline $\begin{array}{l}\text { Sturnus vulgaris } \\
\quad \text { (starling) }\end{array}$ & 700 & $100-120$ & UK & 0.03 & 1.8 & NZ & 0.03 & 1.5 & Ross, 1983 \\
\hline
\end{tabular}

W. Aus., Western Australia; NZ, New Zealand. 
diverse than single reference populations (Browne, 1977; Boileau \& Hebert, 1992). It seems probable that the total level of genetic variation is determined by processes operating after colonization rather than by the circumstances of the colonization event itself. For example, a rapid increase in population size following colonization will prevent any decrease in the level of heterozygosity (Nei et al., 1975) and reduce the likelihood of 'genetic revolutions' such as those envisaged by Mayr (1963). A secondary influx of alleles into established colonies often further enriches the genetic diversity of introduced populations. This appears to be the case for Great Lakes invaders, where the continuous infusion of colonists from numerous Eurasian sources may have created a 'melting pot' of genetic variability.

\section{Acknowledgements}

Funding for this research was provided by a grant from the Natural Sciences and Engineering Research Council of Canada to P. D. N. H. We thank M. Cerny, M. Cornish, P. Gajda, M. Legare, L. Richter, D. Taylor and CCIW for their help in the collection of North American specimens. We also thank M. Cerny, E. Geißler, P. Kasprzak, T. Papenfuß, P. Spaak, N. Walz, L. Weider and F. von Holderberg for their help in collecting European samples. T. Papenfuß aided in the electrophoretic analysis of European specimens. Comments by M. Beaton, M. Boileau and J. Chaplin improved the original manuscript.

\section{References}

ARCHIE, I. W. 1985. Statistical analysis of heterozygosity data: independent sample comparisons. Evolution, 39, 623-637.

AVISE, J. C. 1975. Systematic value of electrophoretic data. Syst. Zool., 23, 465-481.

BAKER, A. J. 1992. Genetic and morphometric divergence in ancestral European and descendent New Zealand populations of chaffinches (Fringilla coelebs). Evolution, 46, 1784-1800.

BAKER, A. J. AND MOOED, A. 1987. Rapid genetic differentiation and founder effect in colonizing populations of common mynas (Acridotheres tristis). Evolution, 41, 525-538.

BALCER, M. D., KORDA, N. L. AND DODSON, S. I. 1984. Zooplankton of the Great Lakes. A Guide to the Identification of the Common Crustacean Species. University of Wisconsin Press, Wisconsin.

BOILEAU, M. G. AND HEBERT, P. D. N. 1991. Genetic consequences of passive dispersal in pond-dwelling copepods. Evolution, 45, 721-733.

BOILEAU, M. G. AND HEBERT, P. D. N. 1992. Genetics of the zebra mussel, Dreissena polymorpha, in populations from the Great Lakes region and Europe. In: Nalepa, T. F. and
Schloesser D. W. (eds) Zebra Mussels: Biology, Impacts and Control, pp. 227-238. Lewis Publishers, Michigan.

BROWNE, R. A. 1977. Genetic variation in island and mainland populations of Peromyscus leucopus. Am. Midl. Nat., 97, $1-9$.

BRYANT, E. H., VAN DIJK, H. AND VAN DELDEN, w. 1981. Genetic variability of the face fly, Musca autumnalis De Geer, in relation to a population bottleneck. Evolution, 35, $872-881$.

CARSON, H. L. 1967. The population flush and its genetic consequences. In: Lewontin, R. C. (ed.) Population Biology and Evolution, pp. 123-138. Proceedings of the International Symposium, Syracuse University Press, New York.

CARTER, J. C. H., DADSWELL, M. J., ROFF, J. C. AND SPRULES, W. G. 1980. Distribution and zoogeography of planktonic crustaceans in glaciated eastern North America. Can. J. Zool., 58, 1355-1387.

COYNE, J. A. AND BARTON, N. H. 1988. What do we know about speciation? Nature, 33, 485-486.

DEEVEY, E. S., Jr AND DEEVEY, G. B. 1971. The American species of Eubosmina Seligo (Crustacea, Cladocera). Limnol. Oceanogr., 16, 201-218.

DEMELO, R. 1993. Speciation in the Freshwater Zooplankton: Provincialism in the Bosminidae. M.Sc. Thesis, University of Guelph.

DEMELO, R. AND HEBERT, P. D. N. 1994. Allozymic variation and species diversity in North American Bosminidae. Can, J. Fish. Aquat. Sci., 51, 873-880.

ENvironment CANADA. 1988. The Great Lakes: An Environmental Atlas and Resource Book. United States Environmental Protection Agency and Environment Canada.

ENVIRONMENTAL PROTECTION SERvice. 1981. The Presence and Implication of Foreign Organisms in Ship Ballast Waters Discharged into the Great Lakes, vols I-II. Environment Canada.

HAVEL, J. E. AND HEBERT, P. D. N. 1993. Daphnia lumholtzi in North America: another exotic zooplankter. Limnol. Oceanogr., 38, 1823-1827.

HEBERT, P. D. N. 1974. Enzyme variability in natural populations of Daphnia magna. I. Population structure in East Anglia. Evolution, 28, 546-556.

HEBerT, P. D. N. 1987. Genetics of Daphnia. In: Peters, R. H. and de Bernardi, R. (eds) 'Daphnia'. Mem. Ist. Ital. Idrobiol., 45, 439-460.

HEBERT, P. D. N. AND BEATON, M. J. 1989. Methodologies for Allozyme Analysis using Cellulose Acetate Electrophoresis. Helena Laboratories, Texas.

HEBERT, P. D. N. AND PAYNE, W. J. 1985. Genetic variation in populations of the hermaphroditic flatworm Mesostoma lingua (Turbellaria, Rhabdocoela). Biol. Bull., 169 , 143-151.

JANSON, K. 1987. Genetic drift in small and recently founded populations of the marine snail Littorina saxatalis. Heredity, 58, 31-37.

JOHNSON, M. S. 1988. Founder effects and geographic variation in the land snail Theba pisana. Heredity, 61, 133-142.

LESSA, E. P. 1990. Multidimensional analysis of geographic genetic structure. Syst. Zool., 39, 242-252. 
LIEDER, U. 1991. The Bosmina kessleri-like morphotype of Eubosmina in Lake Muskoka, Ontario, Canada, as putative interspecific hybrids. Hydrobiologia, 225, 71-80.

MAYR, E. 1963. Animal Species and Evolution. The Belknap Press of Harvard University Press, Massachusetts.

MILlS, E. L., LEACH, J. H., CARLTON, J. T. AND SECOR, C. L. 1991. Exotic Species in the Great Lakes: A History of the Biotc Crises and Anthropogenic Introductions. Great Lakes Fishery Commission Research Completion Report.

NEI, M., MARUYAMA, T. AND CHAKRABORTY, R. 1975. The bottleneck effect and genetic variability in populations. Evolution, 29, 1-10.

PARKIN, D. T. AND COLE, S. R. 1985. Genetic differentiation and rates of evolution in some introduced populations of the House Sparrow, Passer domesticus in Australia and New Zealand. Heredity, 54, 15-23.

ROGERS, J. S. 1972. Measures of genetic similarity and genetic distance. Studies in Genetics, 7, 145-153.

Ross, H. A. 1983. Genetic differentiation of starling (Sturnus vulgaris: Aves) populations in New Zealand and Great Britain. J. Zool. Lond., 201, 351-362.

Ross, K. G. AND TRAGER, J. C. 1990 . Systematics and population genetics of fire ants (Solenopsis saevissima complex) from Argentina. Evolution, 44, 2113-2134.

SOKAL, R. R. 1979. Testing statistical significance of geographic variation patterns. Syst. Zool., 28, 227-232.

SWOFFORD, D. L. AND SELANDER, R. B. 1981. BIOSYS-1: $A$ Computer Program for the Analysis of Allelic Variation in Genetics. Users Manual. University of Illinois at UrbanaChampaign, Urbana, Illinois.

TAYLOR, C. E. AND GORMAN, G. C. 1975. Population genetics of a 'colonizing' lizard: natural selection for allozyme morphs in Anolis grahami. Heredity, 35, 241-247.
TAYLOR, D. J. AND HEBERT, P. D. N. 1993. Habitat-dependent hybrid parentage and differential introgression between neighboringly sympatric Daphnia species. Proc. Natl. Acad. Sci. U.S.A., 90, 7079-7083.

TEMPLETON, A. R. 1980. The theory of speciation via the founder principle. Genetics, 94, 1011-1038.

WARD, R. D. 1977. Relationship between enzyme heterozygosity and quaternary structure. Biochem. Genet., 15, 123-135.

WEIDER, L. J. 1989. Population genetics of Polyphemus pediculus (Cladocera: Polyphemidae). Heredity, 62, 1-10.

WEIDER, L. J. 1991. Allozymic variation in Bythotrephes cederstroemi: a recent invader of the Great Lakes. J. Great Lakes Res., 17, 141-143.

WEIR, B. S. AND COCKERHAM, C. C. 1984 . Estimating $F$-statistics for the analysis of population structure. Evolution, 38, 1358-1370.

WELLS, L. 1970. Effects of alewife predation on zooplankton populations in Lake Michigan. Limnol. Oceanogr., 15, $556-565$.

WOODRUFF, D. S., MULVEY, M. AND YIPP, M. w. 1985. Population genetics of Biomphalaria straminea in Hong Kong. $J$. Heredity, 76, 355-360.

WORKMAN, P. L. AND NisWANDER, J. D. 1970. Population studies on southwestern Indian tribes. II. Local genetic differentiation in the Papago. Am. J. Hum. Genet., 22, 24-49.

YAN, N. D., DUNLOP, W. I., PAWSON, T. W. AND MACKAY, L. E. 1992. Bythotrephes cederstroemi (Schoedler) in Muskoka lakes: first records of the European invader in inland lakes in Canada. Can. J. Fish. Aquat. Sci., 49, 422-426.

ZAR, J. H. 1984. Biostatistical Analysis, 2nd edn., pp. 126-131. Prentice Hall, New Jersey. 